\title{
Can Nanotechnology Antimicrobial Underpant Prevent Bacterial Contamination in Bag Urine Samples: Results of a Preliminary Study
}

\author{
Salih Kavukçu ${ }^{1}$ Seçil Arslansoyu Çamlar ${ }^{1}$ (D) - Alper Soylu ${ }^{1}$
}

Received: 15 January 2019 / Accepted: 1 April 2019 / Published online: 15 April 2019

(C) Dr. K C Chaudhuri Foundation 2019

To the Editor: Urinary tract infections (UTI) are second most common bacterial infections in the childhood. Microorganisms causing UTI are colonized in the perineal region. Non-invasive method of urine collection for culture in infants is application of perineal bag. However, bag urine samples are prone to bacterial contamination [1].

Many antimicrobial technologies are available for textiles; Silver ions, titanium dioxide, gallium, zinc, gold, copper, ammonium, polyhexamethylene biguanid, triclosan and chitosan are used in textile products [2,3]. One of these products is 3-(trimethoxysilyl) propyl dimethyl octadecyl ammonium chloride (Si-QAC) $[4,5]$.

We aimed to investigate whether underpants with antimicrobials decrease the contamination rate in bag urine samples. Infants with bag urine culture results compatible with contamination (either low colony counts or growth of $>1$ bacterial strain) were enrolled. They were divided into two groups. A second (control) bag urine sample was obtained after about $1 \mathrm{~h}$ of wearing of nanotechnology antimicrobial underpants (silane quarternary ammonium compound) without any additional cleansing from the infants in Group 1. Infants in Group 2 gave the control urines without wearing antimicrobial underpants. Groups 1 and 2 were compared for the number of sterile $v s$. contaminated control urine samples. Thirty two infants $(\mathrm{M} / \mathrm{F}=17 / 15)$ with contaminated urine samples were enrolled in the study. They were randomly assigned to Group 1 and Group 2 such that each group included 16 patients. Both groups were similar with respect to M/F ratio (9/7 vs. 8/8 in Groups 1 and 2, respectively, $p>0.05$ ). Control urine cultures were sterile

Seçil Arslansoyu Çamlar

secilars@yahoo.com; secil.camlar@deu.edu.tr

1 Division of Pediatric Nephrology, Department of Pediatrics, Medical Faculty of Dokuz Eylul University, Izmir, Turkey in 1 and 6 infants in Groups 1 and 2, respectively (1/15 vs. $6 / 10, p=0.033)$. Among the nonsterile urine cultures, polymicrobial $v s$. single pathogen growth rates were $12 / 3$ vs. 5/5 in Groups 1 and 2, respectively $(p=0.115)$.

One hour wearing of nanotechnology antimicrobial underpants (silane quarternary ammonium compound) did not prevent bacterial contamination of bag urine samples in infants. Since this is a preliminary study, the number of patients was kept as limited. According to initial results, the study would be continued with more patients in such a way to wear the underwear for a longer time.

Acknowledgments We highly thank Prof. Mehmet Atilla Turkmen from Dokuz Eylul University, Department of Pediatric Nephrology, Izmir, Turkey, for his final editing of the manuscript.

\section{Compliance with Ethical Standards}

Conflict of Interest None.

\section{References}

1. Hoberman A, Wald ER. Urinary tract infections in young febrile children. Pediatr Infect Dis J. 1997;16:11-7.

2. Ramachandran T, Rajendrakumar K, Rajendran R. Antimicrobial textiles - an overview. J Inst Eng. 2004;84:42-7.

3. Dastjerdi R, Montazer M. A review on the application of inorganic nano-structured materials in the modification of textiles: focus on anti-microbial properties. Colloids Surf B Biointerfaces. 2010;79: $5-18$.

4. Li H, Bao H, Bok KX, et al. High durability and low toxicity antimicrobial coatings fabricated by quaternary ammonium silane copolymers. Biomater Sci. 2016;4:299-309.

5. Song J, Kong H, Jang J. Bacterial adhesion inhibition of the quaternary ammonium functionalized silica nanoparticles. Colloids Surf B Biointerfaces. 2011;82:651-6.

Publisher's Note Springer Nature remains neutral with regard to jurisdictional claims in published maps and institutional affiliations. 